\title{
Job Satisfaction in Banks: Relative Significance of Emotional Intelligence and Workplace Environment
}

\author{
Dr. Muhammad Kashif Fida \\ Assistant Professor \\ Riphah International University Islamabad, Lahore Campus Pakistan \\ Muhammad Zohaib Khan Azkaa Safdar \\ Organizational Psychologist Government College University (GCU), Lahore, Pakistan
}

\begin{abstract}
In the current scenario, banking sector is considered a fundamental backbone of every economy in developed and developing countries. The importance of banking was established as it performs major role in every domain of business, as well as in the development of the countries. Banking sector in Pakistan is gradually rising, however, employees in this sector are under a lot of stress due to excessive work load, extra working hours, and in some cases employment insecurity, that may lead to unsatisfactory performance at job. This study highlights the significant positive relationship between bankers' job satisfaction level with their emotional intelligence and workplace environment. It also focuses on the effects that emotional intelligence and workplace environment might have on the banker's job satisfaction level while discussing the contributing demographic factors. The cross-sectional correlational research design was implemented to conduct the study. The data was collected through questionnaire and online surveys from different private and public banking sector employees of Pakistan (Lahore, Karachi, and Islamabad). The purposive sampling strategy was done in two stages, in the first stage, random selection of the branches of different public and private sector banks was completed. In the second one, a sample of 200 employees were selected for data collection according to the set inclusion criteria and their specific posted locations. The conclusions of the study suggested presence of a strong relationship between emotional intelligence, core components of emotional intelligence and workplace environment with job satisfaction of employees. Furthermore, regression analysis indicated that emotional intelligence and workplace environment were the strong predictors of job satisfaction among employees, these variables accounted for 60 percent variance. Demographic variables were established to be of no effect where job satisfaction, emotional intelligence or workplace environment are concerned.
\end{abstract}

Keywords: Job Satisfaction, Workplace Environment, Banking Sector, Cross-sectional Correlational, Emotional Intelligence

DOI: $10.7176 / \mathrm{EJBM} / 11-13-06$

Publication date:May $31^{\text {st }} 2019$

\section{Introduction}

Since the early 2000s, job satisfaction has elicited a great deal of attention from behavioral researchers in organizations, due to its immense importance in the daily performance of employees, and, by extend, organization. Recently, researchers have been more interested in the personal factors affecting job satisfaction, factors such as emotional intelligence of the employees, as emotions perform a critical role in organizational life of an employee (Harrod \& Scheer, 2005). Along with emotional factors, environmental factors of the organization also play a vital role in influencing an employee's job satisfaction.

Job satisfaction, since its formulation, has become among the most important and broadly researched concept in industrial psychology (Dormann \& Zapf, 2001). Researchers have linked satisfaction at workplace to both situational (sociological) and personal (psychological) factors. Situational factors such as job-related conditions like pay, promotion opportunities, and workplace environment, and job characteristics, like task significance, task identity, autonomy, feedback, and skill variety contribute to the satisfaction of the employee (Dormann \& Zapf, 2001; Heller, Judge, \& Watson, 2002). Personal factors comprises of personality traits, personality disposition, self-esteem, emotions and motivation (Dormann \& Zapf, 2001), and these positive traits such as pleasurable engagement, high energy, and enthusiasm contribute positively towards job satisfaction (Heller, Judge, \& Watson, 2002).

In recent times, emotional intelligence has developed as an imperative topic in industrial-organizational psychology (Law, Wong, \& Song, 2004) and researchers have paid special attention to its influence in fundamental organizational outcomes, such as satisfaction and performance in the job (Van Rooy \& Viswesvaran, 2004; Goleman, 2001; Sy, Tram \& O’Hara, 2006; Kafetsios \& Zampetakis, 2008). Emotional intelligence is characterized as 'a person's ability to perceive, express, and regulate emotional responses in one's self as well as in others' (Salovey \& Mayer, 1990). Emotionally intelligence determines how people control their emotions and respond to their frustrations. Moreover, emotionally intelligent individuals are sensitive and 
empathetic towards the emotions of others (Cheung \& Tang, 2009). Emotional intelligence constitutes of four main facets emotional appraisal in one's self (self-awareness), regulation of personal emotions (selfmanagement), recognition of emotions that others are experiencing (social awareness), and using this understanding to better communicate and connect with people (social management) (Mayer \& Salovey, 1997; Goleman, 1998). Employee with more emotional intelligence are able to appropriately cope with the stressors at workplace and are also well-equipped to understand and respond to the emotional responses of their fellows, abilities that greatly enhance their job satisfaction (Mayer \& Salovey, 1997; Druskat, Sala \& Mount, 2006).

Workplace environment includes different characteristic of the job such as, nature of task assigned, level of autonomy available to carry out the work, workplace safety, and relationship with peers as well as subordinates and supervisors. Researches have concluded workplace environment plays a significant role in making employees feel satisfied with their jobs and organization. In case employees are not contented with the task allocated to them, or their working conditions or even their interpersonal relationships, then they are more likely to experience disassociation with their jobs and, in turn, with the organizations (Clark, 1997; Skalli, Theodossiou, \& Vasileiou, 2008; Gazioglu \& Tanselb, 2006; Sousa-Poza \& Sousa-Poza, 2000). Moreover, in current fast pace industry, an organization cannot afford to have dissatisfied employees as it will affect their productivity and standards, or, in case of termination or stepping down, an organization will have to bear additional cost of hiring and training the new employee (Clark, 1997).

Researches, carried out in different work environments stated that employees with better emotional intelligence have better job satisfaction (Kafetsios \& Zampetakis, 2008; Schutte \& Loi, 2014; Sy, Tram \& O'Hara, 2006; Bar-On, 2004; Carmeli, 2003; Prati et al., 2003; Weng et al., 2011). Another study also revealed a significant positive correlation of emotional intelligence, and its dimensions with job satisfaction (Alam, 2009). Emotional intelligence encourages a person to establish interpersonal connections in the work setting (Kafetsios \& Zampetakis, 2008) thus contributing to their success and proficiency in the organization (Prati et al., 2003). Moreover, awareness of the positive and negative aspects of the emotions allows an employee to act in an appropriate way, consequently enhancing job satisfaction (Sy, Tram, O'Hara, 2006). Therefore, employees who use skills underlying emotional intelligence such as, self-confidence, adaptability, empathy, conflict management etc., in their daily work life will feel more proficient in their jobs and satisfied with it (Goleman, 2001).

Employees are a backbone for any organization, and, to ensure their highest performance, they need a workplace environment equipped to provide all the necessary support and tools needed to carry out their duties. Workplace environment includes all the surrounding factors present at a workplace, such as, autonomy given, working hours, communication between peers, subordinates, and superiors and organizational structure. These factors combine to affect satisfaction an employee feels from their job (Lane, Esser, Holte, \& Anne, 2010). Researchers also enacted a motivation model for job satisfaction by sorting job-related factors into two, i.e. hygiene factors, and motivation factors. Results indicated that hygiene factors, such as relationship with supervisor, working conditions, interpersonal relationships etc., greatly effect an employee's chances of being dissatisfied with the job, whereas, motivation factors (sense of achievement, nature of work, opportunities for growth etc.) enhance positive feelings towards a job, and converts lack of satisfaction into satisfaction (Herzberg, Mausne, \& Snyderman, 1959; Baah \& Amoako, 2011). Another research while studying the job satisfaction via economic and workplace variables established that workplace environment, and social support greatly impact job satisfaction, whereas, increase in monetary benefits does not ensure job satisfaction (Sell \& Cleal, 2011). Several researches analyzed the effects of workplace interpersonal relationships on job satisfaction. They establish that with effective relationships, especially with the supervisors, job satisfaction increases (Schroffel, 1999; Castillo \& Cano, 2004). Various researches also established a same pattern of working conditions directly affecting job satisfaction (Arnetz, 1999; Chandrasekar, 2011; Bakotic \& Babic, 2013; Tariq, Ramzan \& Riaz, 2013).

\section{Research Objectives}

- To find out the relationship of employees' job satisfaction with the emotional intelligence and workplace environment.

- To determined the relationship of job satisfaction with core components of emotional intelligence.

- To evaluate the gender difference in terms of job satisfaction, emotional intelligence and workplace environment.

- $\quad$ To established the link between employees' job satisfaction with their sectors.

- To determine the significance between job satisfaction, employees' posted locations.

- To understand various factors which constitute workplace environment.

\section{Hypotheses}

H 1:There is significant relationship among job satisfaction, emotional intelligence, and workplace environment in the banking sector employees.

H 2: Demographic variables, emotional intelligence, and workplace environment significantly predict job 
satisfaction.

H 3: There are significant mean differences in emotional intelligence, workplace environment and job satisfaction in terms of gender, and employees' bank sectors (government and private).

H 4: There are significant mean differences among job satisfaction in terms of employees' banking sectors and their posted locations.

H 5: There would be significant impact of employees' posted locations and banking sectors on employees' level of job satisfaction.

\section{Method}

Research Design. In the current study, cross-sectional correlational research design was implemented to explore the relationship between the under study variables.

Population. The sample included $(\mathrm{N}=200)$ banking sector employees 169 males, and 31 females with the age that ranges from 31 to 50 years. Purposive sampling technique was used to collect the data via questionnaires and online surveys from the different government $(n=86)$ and private $(n=114)$ banking sector employees of Pakistan i.e., Lahore $(n=82)$, Karachi $(n=66)$, and Islamabad $(n=52)$.

Inclusion / Exclusion Criteria. Individuals who are working with the banking sector more than three year, with the age from 30 to 60 years were included in the study. However, the employees serving less than given set time frame or working in contractual basis were exclude from the study.

Instruments. For conducting this research, following instruments were indigenously developed having sound theoretical background on each variable.

Job Satisfaction. Job satisfaction measure for this research consisted upon 30 items measuring various aspects of job satisfaction correspondingly career growth, communication, contingent rewards, corporate social responsibility (CSR), financial stability, fringe benefits, leadership role, meaningfulness of the job, nature of work, organizational pride, remuneration structure, team work and diversity in learning. This scale was developed by Fida, Safdar and Khan (2018). It is a five-point Likert-type rating scale, ranging from $1=$ Completely Disagree to $5=$ Completely Agree. The alpha coefficient level $\alpha=.92$ is indicating that it is a reliable and valid measure to use.

Emotional Intelligence. The scale comprised of 30 items, 5-ponit Likert-type rating scale, ranging from $1=$ strongly disagree to $5=$ strongly agree, having four sub-components emotionality, self-control, sociability and wellbeing. The reported validity of the scale is $\alpha=.92$ (Fida et al., 2018).

Workplace Environment. Workplace environment scale was developed by Fida et al. (2018) and is used to measure the workplace environment in the working setting including green-workplace, operating conditions and general working environment. The 08 items 5-point Likert type rating scale having high Cronbach's' alpha coefficients $\alpha=.81$ is indicating that it is a reliable measure for the research.

Table 1. Frequency Distribution of the sample in terms of Demographic Variables $(N=200)$

\begin{tabular}{lcc}
\hline Variables & $f$ & Percentage (\%) \\
\hline Gender & 169 & 84.5 \\
Male & 31 & 15.5 \\
Female & 113 & 56.5 \\
Age Groups & 87 & 43.5 \\
Age Group I (31-40) & & 42.6 \\
Age Group II (41-50) & 86 & 56.4 \\
Banking Sectors & 114 & 40.6 \\
Government & 82 & 32.7 \\
Private & 66 & 25.7 \\
Posted Locations & 52 & 2.5 \\
Lahore & & 57.5 \\
Karachi & & 12.0 \\
Islamabad & 05 & 24.0 \\
Years wise Experience Categories & 115 & 3.5 \\
(5 to 10.5$)$ & 24 & .5 \\
(10.6 to 15.5$)$ & 48 & 7 \\
(15.5 to 20.5) & 1 & \\
(20.6 to 25.5) & & \\
(25.6 to 30.5) & & \\
(30.6 to 35)
\end{tabular}




\section{Results}

Table 2 .

Psychometric Properties of the Scales $(N=200)$

\begin{tabular}{lcccccc}
\hline & & & & \multicolumn{3}{c}{ Range } \\
\cline { 5 - 6 } Scale & $k$ & $M(S D)$ & $A$ & Potential & Actual & Skew \\
\hline 1. Job Satisfaction & 30 & $80.45(9.87)$ & .92 & $30-150$ & $52-100$ & -.16 \\
2. Emotional Intelligence & 30 & $73.34(6.71)$ & .89 & $30-150$ & $54-93$ & -.03 \\
3. Workplace Environment & 08 & $81.47(9.84)$ & .70 & $08-40$ & $21-40$ & -.29 \\
\hline
\end{tabular}

Note: $k=$ No. of items, $M(S D)=$ Mean (Standard Deviation), $\alpha=$ Cronbach's alpha Coefficients.

Reliability analysis showed that all the research instruments were found to be valid and reliable having sound psychometric properties such as job satisfaction $(\alpha=.92)$, emotional intelligence $(\alpha=.89)$ and work life balance $(\alpha=.70)$.

Table 3.

Correlation among Job Satisfaction, Workplace Environment, and Emotional Quotient $(N=200)$

\begin{tabular}{lcc}
\hline Variable & 2 & 3 \\
\hline 1. Job Satisfaction & $.38^{* *}$ & $.76^{* *}$ \\
2. Emotional Intelligence & - & $.37^{* *}$ \\
3. Workplace Environment & & - \\
\hline
\end{tabular}

Note: $* * p<.01, * p<.05$, (two-tailed)

The results of person product moment correlation indicated that job satisfaction is significantly correlated with emotional intelligence $(r=.38, p<.05)$, and work place environment $(r=.76, p<.01)$ in banking sector employees. Furthermore, work place environment is also significantly associated with emotional intelligence $(r$ $=.37, p<.01)$ of the employees.

Table 4.

Correlation among Job Satisfaction, Emotionality, Sociability, Self-Control and Wellbeing $(N=200)$

\begin{tabular}{llccc}
\hline Variable & 2 & 3 & 4 & 5 \\
\hline 1. Job Satisfaction & $.34^{* *}$ & $.25^{* *}$ & $.37^{* *}$ & $.24^{* *}$ \\
2. Emotionality & - & $.52^{* *}$ & $.70^{* *}$ & $.27^{* *}$ \\
3. Sociability & & - & $.48^{* *}$ & $.34^{* *}$ \\
4. Self-Control & & - & $.34^{* *}$ \\
5. Wellbeing & & & - & - \\
\hline
\end{tabular}

Note: $* * p<.01, * p<.05$, (two-tailed)

Correlation analysis was carried out to investigate the relationship between employees' job satisfaction and sub-facets of emotional intelligence. The results shows that job satisfaction is significantly correlated with emotionality $(r=.34, p<.01)$, sociability $(r=.25, p<.01)$, self-control $(r=.37, p<.01)$, and wellbeing $(r=.24$, $p<.01)$ of the banking sector employees.

Table 5.

Demographic Variables, Emotional Intelligence and Workplace Environment as a Predictors of Job Satisfaction $(N=200)$

\begin{tabular}{lcccc}
\hline & & \multicolumn{2}{c}{$95 \% C I$} & $p$ \\
\cline { 3 - 4 } Predictor & $\beta$ & $U L$ & $L L$ & .57 \\
\hline Constant & 3.21 & 14.57 & -8.14 & .73 \\
Age & .11 & 4.93 & -.21 & .33 \\
Gender & .97 & 5.08 & .21 & .18 \\
Total Experience & -.08 & .41 & -2.10 & .02 \\
Emotional Intelligence & .11 & .30 & .02 & .00 \\
Workplace Environment & .71 & 2.04 & 1.55 & .00 \\
$R^{2}$ & $.60^{* *}$ & & & .00 \\
$F$ & $60.42^{* *}$ & & & $95 \%$ CI \\
\hline
\end{tabular}

Note: ${ }^{*} p<.01 . * p<.05 ; \beta=$ Coefficient of Regression, $L L=$ Lower Limit, $U L=$ Upper limit. 95 CI \%

Multiple linear regression analysis with enter method was used to test if emotional intelligence and workplace environment predicted employees' job satisfaction. The results of regression analysis indicated that two predictors explained $60.4 \%$ of the variance $\left(R^{2}=.60, \mathrm{~F}(5,194)=60.42, \mathrm{p}<.01\right)$. Furthermore, emotional intelligence $(\beta=.11, p<.01)$, and work life balance $(\beta=.71, p<.01)$ were found to be significant predictors of job satisfaction in banking sector employees. 
Table 6.

Mean Differences on Job Satisfaction, in terms Emotional Intelligence and Workplace Environment between Men and Women $(N=200)$

\begin{tabular}{|c|c|c|c|c|c|c|c|c|c|}
\hline \multirow[b]{2}{*}{ Variable } & \multicolumn{2}{|c|}{$\begin{array}{c}\text { Men } \\
(n=169)\end{array}$} & \multicolumn{2}{|c|}{$\frac{\text { Women }}{(n=31)}$} & \multirow[b]{2}{*}{$t(200)$} & \multicolumn{3}{|c|}{$95 \% C I$} & \multirow{2}{*}{ Cohen's $d$} \\
\hline & $M$ & $S D$ & $\vec{M}$ & $S D$ & & $p$ & $L L$ & $U L$ & \\
\hline 1. Job Satisfaction & 80.18 & 9.87 & 81.72 & 9.97 & -.75 & .82 & -5.34 & 2.27 & 0.16 \\
\hline 2. Emotional Intelligence & 73.29 & 6.86 & 73.62 & 5.91 & -.25 & .29 & -2.92 & 2.25 & 0.04 \\
\hline 3. Workplace Environment & 32.67 & 3.96 & 32.12 & 3.81 & .70 & .57 & -.97 & 2.06 & 0.10 \\
\hline
\end{tabular}

Note: $* * p<.01, * p<.05 ; C I=$ Confidence Interval. $L L=$ Lower Limit. $U L=$ Upper Limit.

Results of independent sample $t$-test indicated that there were no significant mean differences between men and women in terms of job satisfaction $(t=-.75, p<.05)$, emotional intelligence $(t=-.25, p<.05)$, and workplace environment $(t=70, p<.05)$.

Table 7.

Mean Differences on Job Satisfaction, in terms of Employees' Banking Sectors (Government and Private) $(N=200)$

\begin{tabular}{|c|c|c|c|c|c|c|c|c|}
\hline \multirow[b]{2}{*}{ Variable } & $\frac{\text { Government }}{\underline{\text { Sector }}}$ & \multicolumn{2}{|c|}{ 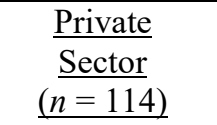 } & \multirow[b]{2}{*}{$t(200)$} & & $\underline{95^{\circ}}$ & $C I$ & \multirow[t]{2}{*}{ Cohen's $d$} \\
\hline & $S D$ & $M$ & $S D$ & & $p$ & $L L$ & $U L$ & \\
\hline 1. Job Satisfaction & 10.38 & 80.56 & 9.52 & -.237 & .81 & -3.12 & 2.54 & 30.18 \\
\hline \multicolumn{9}{|c|}{$\begin{array}{l}\text { Note: }{ }^{* *} p<.01,{ }^{*} p<.05 ; C I=\text { Confidence Interval. } L L=\text { Lower Limit. } U L=\text { Upper Limit. } \\
\quad \text { Results of independent sample } t \text {-test indicated that there were no significant mean differences between men } \\
\text { and women in terms of job satisfaction }(t=-.75, p<.05) \text {, emotional intelligence }(t=-.25, p<.05) \text {, and } \\
\text { workplace environment }(t=70, p<.05) \text {. } \\
\text { Table } 8 \text {. } \\
\text { Impact of Posted Locations and Banking Sectors (Government and Private) on Employees' Job Satisfaction } \\
\text { Level }(\mathrm{N}=200)\end{array}$} \\
\hline Source & & $S S$ & & $d f$ & $M S$ & $F$ & $p$ & $\eta 2$ \\
\hline $\begin{array}{l}\text { Posted Locations } \\
\text { (Lhr. Kch. Isi b) }\end{array}$ & & 26.8 & & 2 & 13.43 & .13 & .87 & 0.01 \\
\hline $\begin{array}{l}\text { Banking Sectors } \\
\text { (Govt. Private) }\end{array}$ & & .57 & & 1 & .57 & .00 & .94 & 0 \\
\hline $\begin{array}{l}\text { Posted Locations* Banking Sectors } \\
\text { within }\end{array}$ & & $\begin{array}{l}114.2 \\
1926\end{array}$ & & $\begin{array}{l}2 \\
194\end{array}$ & $\begin{array}{l}57.13 \\
99.31\end{array}$ & .57 & .56 & 0.06 \\
\hline Error & & 1941 & & 199 & & & & \\
\hline
\end{tabular}

Note: $* * p<.01, * p<.05$, (two-tailed)

Results of two Way-Anova indicated that the interaction effects of employees' job sector and posted locations were found to be non-significant $F(2,194)=.56, p>.05, \eta 2=.06$. Furthermore, the main effects of posted location $F(2,194)=.87, p=n s ., \eta 2=.01$ and employees' sectors were also non-significant $F(1,194)$ $=.94, p=n s, \eta 2=0$.

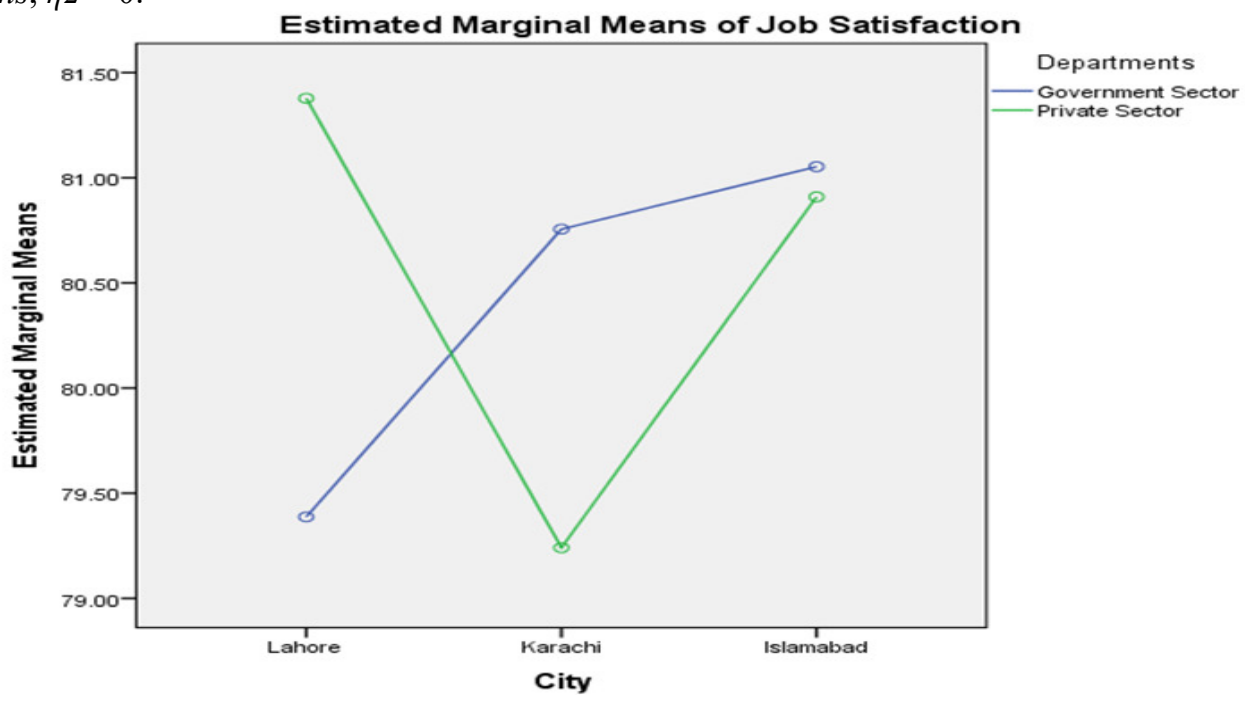




\section{Discussion}

This study was assessed the relationship of job satisfaction with emotional intelligence and workplace environment. Two hundred banking employees (169 (84.5\%) male and $31(15.5 \%)$ female) of public and private sector were selected for data collection. Their ages range from 31 to 50 years $(113(56.5 \%)$ from $31-40$ age range and 87 (43.5\%) from 41-50 age range). Of the 200 sample employees, 86 (42.6\%) were government employees and $114(56.4 \%)$ were from the private banking sector. Experience was sorted into six categories from 5 years' experience to 35 years' experience, experience of 5 (2.5\%) employees fall into 5-10 years range, $115(57.5 \%)$ fall into 10-15 years' experience range, 24 (12.0\%) got experience from 15 to 20 years, 48 (24.0\%) got 20 to 25 years, $7(3.5 \%)$ got 25-30 years' experience, and only $1(0.5 \%)$ got experience in the range of 30-35 years.

Three measures used in this study were prepared indigenously, and they exhibited significant alpha values; job satisfaction $\alpha=.92$, emotional intelligence $\alpha=.89$, and workplace environment $\alpha=.70$. Their significant alpha values depict that they are valid and reliable measures to use in the organizational setting.

It was stated in the first hypothesis that job satisfaction might have a significant relationship with both emotional intelligence and workplace environment. Results supported this assumption that emotional intelligence and workplace environment have a significant positive relationship with job satisfaction. Significant positive relationship between emotional intelligence and job satisfaction had previously been supported by various research studies (Kafetsios \& Zampetakis, 2008; Bar-On, 2004; Sy, Tram \& O'Hara, 2006; Carmeli, 2003; Prati et al., 2003; Weng et al., 2011; Schutte \& Loi, 2014). This significant relationship implies that employees with better emotional intelligence are more satisfied with their jobs because they are more proficient in recognizing and regulating their emotions as well as that of others', thus making them proficient in handling and overcoming tricky situations at work. They are also more conscious of the contributing factors that make them experience emotions whether positive or negative, hence making it possible for them to manage and redirect these factors. Moreover, relationship of workplace environment with job satisfaction was also supported by various prior researches (Schroffel, 1999; Arnetz, 1999; Castillo \& Cano, 2004; Chandrasekar, 2011; Bakotic \& Babic, 2013; Tariq, Ramzan \& Riaz, 2013). Workplace environment, such as having an environmental friendly workplace, safe and thriving operating conditions, and conducive learning surroundings, helps an employee to advance and progress in his work and ensures his satisfaction with the job.

Job satisfaction also significantly correlates with the sub-facets of emotional intelligence; emotionality, sociability, self-control and wellbeing. Emotionality is referred to as a person's capability to perceive and articulate emotions, and to use this ability to form and retain important close relationships. High emotionality ensures that an individual is able to understand, handle and express their emotions in a more conducive way, this helps them to from better relationships in their personal life as well as in work life, increasing their job satisfaction. Employees with better sociability skills are more adept at social interactions. Mastery in social interactions will assure that these employees are adequately able to communicate and listen to people, making their day to day work life far better, and, in turn, enhancing their job satisfaction. People with high self-control have a healthy control over their desires and urges, and are better at fending off impulses and bearing external pressure. All these factors sum up to make a very pleasant and encouraging work life and increase job satisfaction. Individuals with high sense of wellbeing exudes a general sense of fulfillment and accomplishment, and feel more happy, positive and accomplished. This sense of wellbeing reflects in their attitude at work and helps them to accomplish much more, and thus their affecting job satisfaction.

Second hypothesis stated that demographic variables, emotional intelligence, and workplace environment might significantly predict job satisfaction. Results found this statement to be true, which is also the case is various prior researches as well (Sy, Tram \& O'Hara, 2006; Carmeli, 2003; Kafetsios \& Zampetakis, 2008; Prati et al., 2003; Schutte \& Loi, 2014; Schroffel, 1999; Arnetz, 1999; Chandrasekar, 2011; Bakotic \& Babic, 2013). An emotionally intelligent person will be able to navigate the intricacies of a workplace and, will therefore be more satisfied with their job than the one fumbling their way through social interactions. A better workplace environment ensures that a person feels safe and motivated to be able to perform at optimum level, consequently predicting their job satisfaction.

This research failed to accept third hypothesis i.e. gender-wise difference between variables, as no difference was found in this research. Although there are mix responses gender differences between job satisfaction, same conclusion was drawn by several researches done on this topic (Mabekoje, 2009; Klecker, 1997; Pastore, 1994). In prior researches, gender differences were usually related to wage differences present in numerous countries (Fagan \& Burchell, 2002; Young, 1999, Hagedorn, 2001), a phenomenon not common in this society, therefore, gender differences in satisfaction at job are not visible in the current research. Moreover, the results found in this study regarding emotional intelligence and gender are paralleled by the studies previously done (Meshkat \& Nejati, 2017; Shehzad \& Mahmood, 2013; Fernández-Berrocal et al., 2012). Gender differences might be present in the sub-facets of the emotional intelligence, however, complete analysis of emotional intelligence showed no variance. This can be because even if genders have their specific strengths and weaknesses when it comes to emotional intelligence, they balance each other to form a healthy emotionally 
intelligent individual in the society. Lastly, the absence of gender differences in the perception of workplace environment implies the presence of safe and productive work environment for all employees irrespective of the gender.

Furthermore, last hypothesis claimed presence of a difference between government and private sector employees in regards of job satisfaction, results indicated that no such difference is evident in this research, as supported by prior researches (Ahsan, 2017; Sehgal, 2012). Job satisfaction is influenced by several factors surrounding an employee. Factors such as interpersonal relationships, monetary benefits, learning opportunities etc. In this study, employees from both the sectors are fairly satisfied with such factors at their jobs thus making them equally satisfied with their jobs. Moreover, effect of posted the city an individual is performing a job in on job satisfaction, is also found to be insignificant, meaning that pan-country the job satisfaction as well as factors influencing it remains the same.

\section{Conclusion}

This study inspected the association of job satisfaction with emotional intelligence, and workplace environment. Results suggested presence of a significant positive relationship among these variables, however, no gender differences were identified in this sample. For any organization to work at their optimal level, they need their human resource at their finest. Banking sector is no exception here. Adding further financial responsibility to an already hectic and challenging work only fuels the stress of the employees and affect their satisfaction regarding their profession. This research will be a substantial addition to the literature of job satisfaction, emotional intelligence and workplace environment, and will help organizations, researchers and human resource personnel alike to understand these phenomenon, thereby taking initiatives to improve and better their job satisfaction, as a satisfying employee is a productive employee.

\section{References}

Ahsan, M. K. (2017). A Comparison of Job Satisfaction of Private and Public Banks' Employees. Journal for Studies in Management and Planning, 3(6), 76-92.

Alam, M. M. (2009). The relationships between the emotional intelligence and job satisfaction: Empirical findings from higher education institution in Malaysia. Journal of Management and Social Sciences, 5(2), 124-139.

Arnetz, B. B. (1999). Staff perception of the impact of health care transformation on quality of care. International Journal for Quality in Health Care, 11(4), 345-351.

Baah, K., \& Amoako, G. K. (2011). Application of Frederick Herzberg's two-factor theory in assessing and understanding employee motivation at work: A Ghanaian perspective. European Journal of Business and Management, 3(9), 1-8.

Bakotic, D., \& Babic, T. B. (2013). Relationship between working conditions and job satisfaction: The case of Croatian Shipbuilding Company. International Journal of Business and Social Science, 4(2), 206-213.

Bar-On, R. (2004). The Bar-On Emotional Quotient Inventory (EQ-I): Rationale, description, and summary of psychometric properties. In G. Geher, (Ed.), Measuring Emotional Intelligence: Common Ground and Controversy (pp. 111-142). New York: Nova Science Publishers.

Castillo, J. X., \& Cano, J. (2004). Factors explaining job satisfaction among faculty. Journal of Agricultural Education, 45(3), 65-74. doi: 10.5032/jae.2004.03065.

Carmeli, A. (2003). The relationship between emotional intelligence and work attitudes, behavior and outcomes. Journal of Managerial Psychology, 18(8), 788-813. doi: 10.1108/02683940310511881.

Chandrasekar, K. (2011). Workplace environment and its impact organizational performance in public sector organizations. International Journal of Enterprise Computing and Business Systems, 1(1), 1-19.

Cheung, F. Y., \& Tang, C. S. (2009). The influence of emotional intelligence and affectivity on emotional labor strategies at work. Journal of Individual Differences, 30(2), 75-86. doi: 10.1027/1614-0001.30.2.75.

Clark, A. E. (1997). Job satisfaction and gender: Why are women so happy at work? Labour Economics, 4(4), 341-372. doi: 10.1016/S0927-5371(97)00010-9.

Druskat, V. U., Sala, F., \& Mount, G. (2006). Linking Emotional Intelligence and Performance at Work: Current Research Evidence with Individuals and Groups. Mahwah, New Jersey: Erlbaum.

Dormann, C., \& Zapf, D. (2001). Job satisfaction: A meta-analysis of stabilities. Journal of Organizational Behavior, 22(5), 483-504. doi: 10.1002/job.98.

Fagan, C., \& Burchell, B. Office for Official Publications of the European Communities. (2002). Gender, jobs and working conditions in the European Union. (pp. 1-92). Retrieved from edz.bib.uni-mannheim.de/wwwedz/pdf/ef/02/ef0249en.pdf.

Fernández-Berrocal, P., Cabello, R., Gualda, R. C., \& Extremera, N. (2012). Gender differences in emotional intelligence: The mediating effect of age. Behavioral Psychology/Psicologia Conductual 20(1), 77-89.

Fida, M. K., Safdar, A., \& Khan, M. Z. (2018). Combined Effects of Work-Life Balance, and Emotional 
Intelligence on Employees' Job Satisfaction. Manuscript in preparation.

Gazioglu, S., \& Tanselb, A. (2006). Job satisfaction in Britain: Individual and job related factors. Applied Economics, 38(10), 1163-1171. doi: 10.1080/00036840500392987.

Goleman, D. (1998). Working with Emotional Intelligence. New York: Bantam Books.

Goleman, D. (2001). An EI-based theory of performance. In C. Cherniss, \& D. Goleman, (Eds.), The Emotionally Intelligent Workplace: How to Select for, Measure, and Improve Emotional Intelligence in Individuals, Groups, and Organizations (pp. 27-44). San Francisco, CA: Jossey-Bass.

Hagedorn, L. S. (2001). Gender Differences in Faculty Productivity, Satisfaction, and Salary: What Really Separates Us? Retrieved from ERIC Database. (ED464548).

Harrod, N. R., \& Scheer. S. D. (2005). An exploration of adolescent emotional intelligence in relation to demographic characteristics. Adolescence, 40(159), 503-512.

Heller, D., Judge, T., \& Watson, D. (2002). The confounding role of personality and trait affectivity in the relationship between job and life satisfaction. Journal of Organizational Behavior, 23(7), 815-835. doi: 10.1002/job.168.

Herzberg, F., Mausne, B., \& Snyderman, B. (1959). The Motivation to Work (2 ${ }^{\text {nd }}$ ed.). Oxford, England: John Wiley.

Kafetsios, K., \& Zampetakis, L. A. (2008). Emotional intelligence and job satisfaction: Testing the mediatory role of positive and negative affect at work. Personality and Individual Differences, 44(3), 710-720. doi: 10.1016/j.paid.2007.10.004.

Klecker, B. (1997). Male elementary school teachers' ratings of job satisfaction by years of teaching experience. Education, 3-13.

Lane, K., Esser, J., Holte, B., \& Anne, M. M. (2010). A study of nurse faculty job satisfaction in community colleges in Florida. Teaching and Learning in Nursing, 5(1), 16-26. doi: 10.1016/j.teln.2009.05.001.

Law, K. S., Wong, C. S., \& Song, L. J. (2004). The construct and criterion validity of emotional intelligence and its potential utility for management studies. The Journal of Applied Psychology, 89(3), 483-496. doi: 10.1037/0021-9010.89.3.483.

Locke, E. A. (1976). The nature and causes of job satisfaction. In M. D. Dunnette (Eds.), Handbook of Industrial and Organizational Psychology (pp. 1297-1350). Chicago: Rand McNally.

Mabekoje, S. O. (2009). Gender differences in job satisfaction among secondary school teachers. African Journal of Research in Personnel and Counselling Psychology, 1(1), 99-108.

Mayer, J. D., \& Salovey, P. (1997). What is emotional intelligence? In D. Sluyter \& P. Salovey (Eds.), Emotional Development and Emotional Intelligence: Implications for Educators (pp. 3-31). New York: Basic Books.

Meshkat, M., \& Nejati, R. (2017). Does Emotional Intelligence Depend on Gender? A Study on Undergraduate English Majors of Three Iranian Universities. SAGE Open, 7(3). Retrieved form https://journals.sagepub.com/doi/full/10.1177/2158244017725796.

Pastore, D. L. (1994). Job satisfaction and female college coaches. Physical Educator, 50(4), 216-221.

Prati, L. M., Douglas, C., Ferris, G. R., Ammeter, A. P., \& Buckley, M. R. (2003). Emotional intelligence, leadership effectiveness, and team outcomes. International Journal of Organizational Analysis, 11(1), 2140. doi: 10.1108/eb028961.

Salovey, P., \& Mayer, J. D. (1990). Emotional intelligence. Imagination, Cognition, and Personality, 9(3), $185-$ 211. doi: 10.2190/DUGG-P24E-52WK-6CDG.

Schroffel, A. (1999). How does clinical supervision affect job satisfaction? The Clinical Supervisor, 18(2), 91105. doi: $10.1300 / \mathrm{J} 001 \mathrm{v} 18 \mathrm{n} 0207$.

Schutte, N. S., \& Loi, N. M. (2014). Connections between emotional intelligence and workplace flourishing. Personality and Individual Differences, 66, 134-139. doi: 10.1016/j.paid.2014.03.031.

Sehgal, S. (2012). Job Satisfaction of Bank Employees in Shimla: A Comparative Study of Private \& Public Sector Bank. International Journal of Marketing, Financial Services \& Management, 3(6), 124-146.

Sell, L., \& Cleal, B. (2011). Job satisfaction, work environment, and rewards: Motivational theory revisited. Labour, 25(1), 1-23. doi: 10.1111/j.1467-9914.2010.00496.x.

Shehzad, S., \& Mahmood, N. (2013). Gender Differences in Emotional Intelligence of University Teachers. Pakistan Journal of Social and Clinical Psychology, 11(1), 16-21.

Skalli, A., Theodossiou, I., \& Vasileiou, E. (2008). Jobs as Lancaster Goods: Facets of job satisfaction and overall job satisfaction. The Journal of Socio-Economics, 37(5), 1906-1920. doi: 10.1016/j.socec.2008.04.003.

Sousa-Poza, A., \& Sousa-Poza, A. (2000, May). Taking another look at the gender/job-satisfaction paradox. Kyklos: International Review of Social Science, 53(2), 135-152. doi: 10.1111/1467-6435.00114.

Sy, T., Tram, S., \& O'Hara, L. A. (2006). Relation of employee and manager emotional intelligence to job satisfaction and performance. Journal of Vocational Behavior, 68(3), 461-473. doi: 
10.1016/j.jvb.2005.10.003

Tariq, M., Ramzan, M., \& Riaz, A. (2013). The impact of employee turnover on the efficiency of the organization. Interdisciplinary Journal of Contemporary Research in Business, 4(9), 700-711.

Van Rooy, D. L., \& Viswesvaran, C. (2004). Emotional intelligence: A meta-analytic investigation of predictive validity and nomological net. Journal of Vocational Behavior, 65(1), 71-95. doi: 10.1016/S00018791(03)00076-9.

Vroom, V. (1964). Work and Motivation. New York: John Wiley and Sons.

Weng, H. C., Hung, C. M., Liu, Y. T., Cheng, Y. J., Yen, C. Y., Chang, C. C., \& Huang, C. K. (2011) Associations between emotional intelligence and doctor burnout, job satisfaction and patient satisfaction. Medical Education, 45(8), 835-842. DOI: 10.1111/j.1365-2923.2011.03985.x.

Young, I. P. (1999). Salary discrimination: A test of the paradoxical female hypothesis. Educational Administration Quarterly, 35(3), 379-397. 